\title{
PENGARUH MANAJEMEN KOPERASI DALAM MENINGKATKAN SISA HASIL USAHA (SHU) DI KOPERASI
}

\author{
Florida Ningsih ${ }^{1}$, Sutar $^{2}$ \\ ${ }^{1}$ STIE Muhammadiyah Jakarta, florida@stiemj.ac.id \\ ${ }^{2}$ STIE Muhammadiyah Jakarta, sutarse09@gmail.com
}

\begin{abstract}
ABSTRAK
Penelitian ini bertujuan untuk mengetahui apakah koperasi kredit SEHATI telah menerapkan manajemen koperasi yang baik dan benar dalam usaha meningkatkan SHU ( sisa hasil usaha ). Penelitian mengambil data primer dalam Kuesioner yang disebarkan kepada Anggota. Di Koperasi SEHATI berfokus pada kopdit kantor cabang cakung Jakarta Timur dengan jumlah 265 orang anggota aktif. Data tersebut kemudian dianalisis menggunkan Uji Validitas dan Reliabilitas, dan Uji Koefisien Determinasi, Uji t, untuk menguji hipotesis penelitian. Berdasarkan Uji T manajemen koperasi (X) berpengaruh secara positif dan signifikan terhadap peningkatan sisa hasil usaha (Y).

Kata kunci : Manajemen Koperasi dan Sisa Hasil Usaha.

\section{ABSTRACT}

This study aims to determine whether SEHATI credit cooperatives have implemented good and correct cooperative management in an effort to improve SHU (remaining operating results). This study took primary data in a questionnaire that was distributed to members. At SEHATI Cooperative, the focus is on the East Jakarta cakung branch office cooperative with 265 active members. The data were then analyzed using the Validity and Reliability Test, and the Coefficient of Determination Test, the $t$ Test, to test the research hypothesis. Based on the T test, the influence of cooperative management together has a positive effect on residual business results. Y).
\end{abstract}

Keywords : Cooperative Management and Remaining Results

\section{PENDAHULUAN}

Dalam usaha pemulihan krisis ekonomi Indonesia dewasa ini, sesungguhnya koperasi mendapatkan peluang untuk tampil lebih eksis. Krisis ekonomi yang diawali dengan krisis nilai tukar dan kemudian membawa krisis hutang luar negeri, telah membuka mata semua pemerhati ekonomi.

Indonesia merupakan salah satu negara yang tergolong sebagai negara yang berkembang, dimana dalam struktur perekonomiannya secara garis besar terdapat tiga pelaku ekonomi yaitu badan usaha milik negara (BUMN), badan usaha milik swasta (BUMS), dan koperasi. Ketiga usaha tersebut hidup secara seimbang dan saling membantu dalam tata perekonomian Indonesia. Namun sangat disayangkan koperasi masih jauh tertinggal dari pada kedua usaha lainnya.

Koperasi mempunyai peran yang cukup besar dalam menyusun usaha bersama dari orang- 
orang yang mempunyai kemampuan ekonomi terbatas, usaha ini bertujuan untuk memenuhi kebutuhan yang dirasakan bersama, yang pada akhirnya mengangkat harga diri, meningkatkan kedudukan, serta kemampuan untuk mempertahankan diri dan membebaskan diri dari kesulitan.

Berhasil tidaknya koperasi sangat tergantung dari manajemennya. Apabila manajemen koperasi bagus maka besar kemungkinan koperasi akan maju dan dapat mengantisipasi, meminimalisasi kerugian dan masalah yang ada pada koperasi. Akan tetapi jika manajemennya jelek maka koperasi akan mudah terancam dengan masalah-masalah yang muncul, baik masalah yang besar maupun masalah kecil akan berpengaruh buruk bagi koperasi dan mengalami kemunduran.

Koperasi kredit SEHATI dalam menjalankan aktivitas koperasi banyak mengalami hambatan sehingga menyebabkan manajemen koperasi tidak berjalan dengan semestinya, hal ini ditandai dengan adanya anggota yang tidak bertanggungjawab atau lepas tanggungjawab terhadap koperasi. Lepas tanggungjawab disini maksudnya adalah seperti ketidak jujuran para anggota, kurangnya rasa kesadaran dari para anggota untuk mengembalikan pinjaman tepat pada waktunya atau tidak melampaui batas pembayaran yang telah ditentukan oleh pihak koperasi.

Dengan adanya penurunan partisipasi keaktifan anggotanya, ini menyebabkan kegiatan unit usaha yang dijalankan pada koperasi tersebut menjadi menurun sehingga sisa hasil usaha (SHU) yang diperoleh menjadi menurun juga, hal tersebut membuat sisa hasil usaha (SHU) yang diinginkan oleh koperasi sehati tidak sesuai dengan target yang diharapkan. Hal ini sejalan dengan penelitian yang dilakukan oleh Winda Alfiani (2016) bahwa pengaruh partisipasi anggota koperasi terhadap sisa hasil usaha memiliki pengaruh yang positif. Selain itu penelitian yang dilakukan oleh Monica Tria Cahyani, Anjuman Zukhri, Made Ary Meitriana, juga menunjukkan bahwa terdapat pengaruh langsung antara jumlah anggota terhadap perolehan sisa hasil usaha pada Koperasi Simpan Pinjam Wisuda Guna Raharja Denpasar tahun 2012-2014 sebesar 0,353, dan terdapat pengaruh tidak langsung antara jumlah anggota terhadap perolehan sisa hasil usaha melalui partisipasi anggota pada Koperasi Simpan Pinjam Wisuda Guna Raharja Denpasar tahun 2012-2014 sebesar 0,6646.

Berdasarkan uraian tersebut diatas maka penulis termotivasi untuk melakukan penelitian dengan judul Pengaruh Manajemen Koperasi Dalam Meningkatkan SHU (Sisa Hasil Usaha) pada Koperasi Kredit SEHATI.

\section{KAJIAN PUSTAKA \\ Manajemen Koperasi}

Manajemen koperasi membuat keputusan guna mencapai tujuan-tujuan atau sasaran usaha koperasi. Adapun keputusan itu meliputi perencanaan (planning), pengorganisasian (organizing), susunan karyawan (staffing), pengkoordinasian (coordinating), pengendalian (controlling), dan pengarahan (directing).

Menurut sukamdiyo (2006:8) manajemen koperasi adalah cara bagaimana mengatur koperasi agar dapat mencapai tujuan. Mengatur atau mengelola koperasi berdasarkan efisiensi dapat meningkatkan kesejahteraan para anggotanya.

\section{Prinsip-Prinsip Koperasi}

Perkoperasian adalah segala sesuatu yang menyangkut kehidupan koperasi. Gerakan koperasi adalah keseluruhan organisasi koperasi dan kegiatan perkoperasian yang bersifat terpadu menuju 
tercapainya cita-cita bersama koperasi. Perkoperasian di Indonesia diatur dengan undang-undang nomor 25 tahun 1992yang berlandaskan Pancasila dan UUD 1945, dan bertujuan memajukan kesejahteraan anggota pada khususnya dan masyarakat pada umumnya serta ikut membangun tatanan perekonomian nasional dalam rangka mewujudkan masyarakat yang maju, adil, dan makmur. Koperasi bekerja berdasarkan beberapa prinsip, prinsip ini merupakan pedoman bagi koperasi dalam melaksanakan nilai-nilai koperasi. Prinsip-prinsip dalam koperasi adalah sebagai berikut :

a. Keanggotaan sukarela dan terbuka. Koperasi adalan yang keanggotaannya bersifat sukarela, terbuka bagi semua orang bersedia menggunakan jasa-jasanya, dan bersedia menerima tanggung jawab keanggotaan tanpa membedakan gender, latar belakang social, ras, polotik, atau agama.

b. Pengawasan oleh anggota secara demokratis, koperasi adalah organisasi demokratis yang diawasi oleh anggotanya. Yang secara aktif menetapkan kebijakan dan membuat keputusan laki-laki dan perempuan yang dipilih sebagai pengurus atau pengawas bertanggung jawab kepada rapat anggota dalam koperasi perimer, anggota memilikihak suara yang sama (atu anggota satu suara) dkelola secara demokratis.

c. Partisipasi anggota dalam kegiatan ekonomi. Anggota menyetorkan modal mereka secara adil dan melakukan pengawasan secara demokratis. Sebagiam modal tersebut adalah milik bersama. Bila ada balas jasa terhadap modal, diberikan secara terbatas. Anggota mengalokasikan SHU untuk beberapa atau semua dari tujuan seperti dibawah ini :

a) Mengembangkan koperasi. Caranya dengan membentuk dana cadangan, yang sebagian dari dana itu tidak dapat dibagikan.

b) Dibagikan kepada anggota. Caranya seimbang berdasarkan transaksi mereka dengan koperasi.

c) Mendukung keanggotaan lainnya yang disepaki dalam rapat anggota.

d. Otonomi dan kemandirian. Koperasi adalah organisasi otonom dan mandiri yang diawasioleh anggotanya. Apabila koperasi membuat perjanjiandengan pihak lain, termasuk pemerintah,atau memperoleh modal dari luar, maka hal itu harus berdasarkan persyaratan yang tetap menjamin upaya adanya, pengawasahhhhhn yang demokratis dari anggotanya, mempertahankan otonomi koperasi.

e. Pendidikan, pelatihan, dan informasi. Koperasi memberikan pendidikan dan pelatihan bagi anggota, pengurus, manager, dan karyawan. Tujuannya, agar mereka dapat melaksanakan tugas dengan lebih efektif bagi perkembangan koperasi. Koperasi memberikan informasi kepada masyarakat umum, khususnya orang-orang muda dan tokoh-tokoh masyarakat mengenai hakekat dan manfaat koperasi.

f. Kerjasama antar koperasi. Dengan bekerjasama pada tingkat local, regional dan internasional, maka gerakan koperasi dapat melayani anggotanya dengan efektif, dan dapat memperkuat gerakan koperasi.

g. Kepedulian terhadap masyarakat. Koperasi melakukan kegiatan untuk pengembangan masyarakat sekitarnya secara berkelanjutan melalui kebijakan yang diputuskan oleh rapat anggota. 


\section{JURNAL EKOBIS: EKONOMI, BISNIS \& MANAJEMEN Volume 9, Nomor 1, Maret (2019)}

\section{Sisa Hasil Usaha (SHU)}

Sisa hasil usaha (SHU) koperasi diatur dalam pasal 45 UU Nomor 25 Tahun 1992. Ayat (1) memberikan batasan SHU, yaitu pendapatan koperasi diperoleh dalam satu tahun buku dikurangi biaya, penyusutan, dan kewajiban lainnya termasuk pajak dalam tahun buku yang bersangkutan. Sedangkan Ayat (2) menjelaskan cara membagi SHU dan pemanfaatannya.

Pembagian SHU yang diterima anggota atau sisa hasil usaha bagian anggota dilakukan secara adil dan sebanding dengan besarnya jasa usaha masing-masing anggota. dengan demikian, sisa hasil usaha yang diterima anggota adalah harus sebanding dengan jasa usaha yang disebut SHU bagian anggota atas jasa usaha. Yang dimaksud jasa usaha adalah transaksi usaha dan partisipasi modal.

SHU merupakan laba atau keuntungan yang diperoleh dari menjalankan usaha sebagaimana layaknya sebuah perusahaan bukan koperasi. SHU tersebut merupakan hasil akhir dari komponen-komponen yang menghasilkan dikurangi dengan jumlah komponen-komponen biaya. Jadi dapat disimpulkan SHU merupakan laba atau pendapatan koperasi yang diperoleh dalam satu tahun buku setelah dikurangi dengan biaya, penyusutan dan biaya lainnya termasuk pajak dalam tahun buku yang bersangkutan.

Selisih antara penghasilan yang diterima selama periode tertentu dengan pengorbanan yang dikeluarkan untuk pemperoleh penghasilan di dalam koperasi di sebut Sisa Hasil Usaha (SHU). SHU ini setelah dikurangi dengan biaya-biaya tertentu akan dibagikan kepada para anggota sesuai dengan perimbangan jasanya masing-masing.

Jasa anggota diukur berdasarkan jumlah kontribusi masing-masing terhadap pembentukan SHU ini. Ukuran kontribusi yang digunakan adalah jumlah transaksi anggota dengan koperasi selama periode tertentu.

\section{METEDOLOGI PENELITIAN}

Gambar 1. Kerangka Pikir

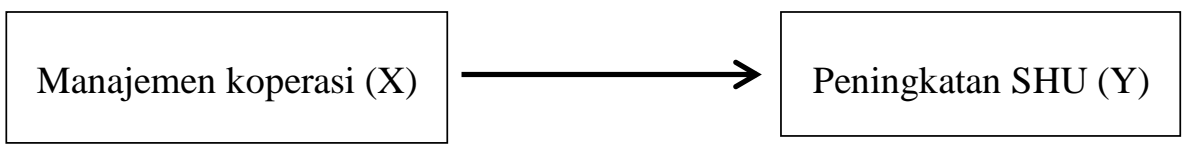

Penelitian ini dilakukan di koperasi SEHATI dengan manajemen koperasi sebagai variabel independen (X) dalam meningkatkan SHU sebagai variabel dependen (Y). Populasi dalam penelitian ini adalah anggota yang bergabung dalam koperasi SEHATI (kantor cabang cakung) yang berjumlah 265 orang. Penentuan jumlah sample dilakukan dengan menggunakan rumus menurut Slovin dengan tingkat toleransi yang ditetapkan adalah $10 \%$.

$$
n=\frac{N}{1+N(e)^{2}}
$$


Keterangan:

$\mathrm{N}=$ Ukuran populasi yaitu jumlah aggota koperasi SEHATI pada kantor cabang cakung sebanyak 265 orang

$\mathrm{E}=$ Proses kelonggaran ketidaktelitian karena kesalahan pengambilan sample yang masih dapat ditolerir atau diinginkan, sebesar $10 \%$

$\mathrm{n} \quad=$ Ukuran sample

Maka :

$\mathrm{n}=72,60=73$

Dari hasil perhitungan dengan rumus Slovin tersebut diperoleh sample sebanyak 73 orang.

\section{HASIL DAN PEMBAHASAN}

\section{Karakteristik Responden}

Dari 75 kuesioner yang digunakan, menunjukkan bahwa responden wanita lebih banyak dibanding pria yaitu 45 orang $(56,7 \%)$ pria dan 30 orang $(43,30 \%)$ wanita. Usia responden yang terbanyak adalah yang berumur antara 21 - 30 tahun sebanyak 48 orang $(68,90 \%)$, diikuti dengan usia responden yang memiliki usia 31 - 40 tahun sebanyak 20 orang $(22,20 \%)$. Responden berlatar belakang keanggotaan selama kurang dari 1 tahun berjumlah sebanyak 16 orang dan 1 orang sebagai pegawai negeri, $1-2$ tahun berjumlah 15 orang dan kebanyakan bekerja sebagai pegawai swasta berjumlah sebanyak 57 orang. sedangkan keanggotaan selama $2-3$ tahun berjumlah sebanyak 27 orang dan 6 orang sebagai ibu rumah tangga dan keanggotaan selama $3-4$ tahun berjumlah sebanyak 15 orang dan 11 orang sebagai pekerja lainnya dan dengan keanggotaan selama lebih dari 5 tahun berjumlah 2 orang. Sebagian besar penghasilan perbulan > Rp. 4.000.000,sebanyak 39 orang dan 1 orang di antaranya bekerja sebagai pegawai negeri. Penghasilan perbulan sebesar Rp. 3.000.000 - Rp. 4.000 .000 berjumlah 20 orang dan kebanyakan bekerja sebagai pegawai swasta berjumlah 60 orang sedangkan yang berpenghasilan perbulan sebesar Rp. 2.000 .000 - Rp. 3.000 .000 berjumlah 14 orang diantaranya 8 orang pegawai lainnya dan berpenghasilan perbulan sebesar Rp. 1.000 .000 - Rp. 2.000 .000 berjumlah 1 orang dan berpenghasilan perbulan sebesar < Rp. 1.000 .000 berjumlah 1 orang.

\section{Analisis Data}

\section{Analisis Deskriptif}

Dalam hal ini dikemukakan mengenai deskripsi jawaban responden terhadap variabelvariabel yang diteliti, sehingga akan dapat diketahui intensitas kondisi masing-masing variabel didasarkan pada nilai skor raat-rata (indeks) yang dikategorikan dalam rentang skor berdasarkan tree box methode (Augusty Ferdinand, 2006) berikut ini :

Batas atas rentang skor: $(\% \mathrm{~F} \times 5) / 5=(75 \% \times 5) / 5=375 / 5=75$

Batas bawah rentang skor: $(\% \mathrm{~F} \times 1) / 5=(75 \%$ x 1$) / 5=75 / 5=15$

Angka indeks yang dihasikan akan dimulai dari 15 hingga 75, dengan rentang sebesar 60 dibagi 3, menghasilkan rentang sebesar 20 yang akan digunakan sebagai interpretasi nilai indeks sebagai berikut :

\begin{tabular}{|ccc|c|}
\hline $15,00-35,00$ & Rendah \\
\hline $35,00-55,00$ & Sedang \\
\hline $55,00-75,00$ & Tinggi \\
\hline
\end{tabular}




\section{Analisis Deskriptif Manajemen Koperasi}

Manajemen koperasi membuat keputusan guna mencapai tujuan-tujuan atau sasaran usaha koperasi. Adapun keputusan itu meliputi perencanaan (planning), pengorganisasian (organizing), susunan karyawan (staffing), pengkoordinasian (coordinating), pengendalian (controlling), dan pengarahan (directing).

TABEL 1

TANGGAPAN RESPONDEN MENGENAI MANAJEMEN KOPERASI

\begin{tabular}{|c|c|c|c|c|c|c|c|c|}
\hline \multirow[t]{2}{*}{ No } & \multirow[t]{2}{*}{ Pertanyaan } & \multicolumn{5}{|c|}{ Skor } & \multirow[t]{2}{*}{ Skor } & \multirow[t]{2}{*}{ Indeks } \\
\hline & & SS & $\mathrm{S}$ & $\mathrm{CS}$ & TS & STS & & \\
\hline 1 & $\begin{array}{l}\text { Perencanaan manajemen koperasi sehati } \\
\text { dapat meningkatkan kinerja koperasi }\end{array}$ & 28 & 41 & 4 & 0 & 0 & 316 & 63,2 \\
\hline 2 & $\begin{array}{l}\text { Koperasi sehati memberikan pelayanan } \\
\text { yang baik kepada anggota }\end{array}$ & 26 & 40 & 8 & 1 & 0 & 316 & 63,2 \\
\hline 3 & $\begin{array}{l}\text { Koperasi menetapkan kebijakan SDM } \\
\text { dalam mencapai tujuan }\end{array}$ & 23 & 43 & 9 & 0 & 0 & 314 & 62,8 \\
\hline 4 & $\begin{array}{l}\text { Koperasi menetapkan kebutuhan kerja } \\
\text { karyawan }\end{array}$ & 19 & 38 & 16 & 1 & 0 & 297 & 59,4 \\
\hline 5 & $\begin{array}{l}\text { Koperasi sehati memberikan pengarahan } \\
\text { pengawas kepada anggota }\end{array}$ & 23 & 42 & 10 & 0 & 0 & 313 & 62,6 \\
\hline 6 & $\begin{array}{l}\text { Koperasi sehati memberikan pengarahan } \\
\text { pengurus kepada karyawan }\end{array}$ & 24 & 36 & 14 & 1 & 0 & 308 & 61,6 \\
\hline 7 & $\begin{array}{l}\text { Koperasi mengadakan pertemuan resmi } \\
\text { antar anggota koperasi }\end{array}$ & 28 & 38 & 9 & 0 & 0 & 319 & 63,8 \\
\hline 8 & $\begin{array}{l}\text { Koperasi sehati mengadakan arus informasi } \\
\text { yang memadai }\end{array}$ & 23 & 41 & 11 & 0 & 0 & 312 & 62,4 \\
\hline 9 & $\begin{array}{l}\text { Koperasi sehati memberikan pengawasan } \\
\text { pengurus terhadap karyawan }\end{array}$ & 14 & 48 & 12 & 1 & 0 & 300 & 60 \\
\hline 10 & $\begin{array}{l}\text { Koperasi sehati memberikan pengawasan } \\
\text { pengurus terhadap anggota }\end{array}$ & 19 & 45 & 11 & 0 & 0 & 308 & 61,6 \\
\hline & Jumlah & & & & & & 3103 & 620,6 \\
\hline & Rata - Rata & & & & & & 310 & 62,6 \\
\hline
\end{tabular}

Sumber : hasil pengolahan data 2018

Keterangan :

Nilai jumlah $=316$ diperoleh dari $(5 \times 28)+(4 \times 41)+(3 \times 4)$

Nilai Indeks $=$ Nilai jumlah $/ 5=316 / 5=63,2$

Nilai Indeks Total $=(63,2+63,2+62,8+59,4+62,6+61,6+63,8+62,4+60+61,6) / 10=$ $620,6 / 10=62,6$

Berdasarkan, diketahui bahwa sebagian besar responden memberikan penilaian yang baik atas manajemen koperasi yang rasakan oleh anggota koperasi Sehati. Rata - rata skor jawaban variabel manajemen koperasi diperoleh sebesar 62,6 yang berada dalam kategori skor "Tinggi" 
hal ini menunjukkan adanya manajemen koperasi yang baik telah memberikan pengaruh terhadap peningkatan SHU.

\section{Deskripsi Variabel Sisa Hasil Usaha}

Factor - factor yang mempengaruhi SHU terdiri dari 2 faktor yaitu factor dalam dan factor luar :

1. Factor dari dalam

a. Partisipasi anggota, para anggota harus berpartisipasi dalam kegiatan koperasi karena tanpa adanya peran angggota maka koperasi tidak akan berjalan lancar.

b. Jumlah modal sendiri, SH7U anggota yang diperoleh sebagian dari modal sendiriaitu dari simpanan wajib, simpanan pokok, dana cadangan dan hibah.

c. Kinerja pengurus, kinerja pengurus sangat diperlukan dalam semua kegiatan yang dilakukan oleh koperasi. Dengan adanya kinerja yang baik dan sesuai persyaratan dalam anggaran dasar serta UU perkoperasian maka hasil yang dicapaipun juga akan baik.

d. Jumlah unit usaha yang dimiliki, setiap koperasi pasti memiliki unit usaha hal ini juga menentukan seberapa besar volume usaha yang di jalankan dalam kegiatan usaha tersebut.

e. Kinerja manajer, kinerja manajer menentukan jalannya semua kegiatan yang dilakukan oleh koperasi dan memiliki wewenang atas semua hal - hal yang bersifat intern.

f. Kinerja karyawan, merupakan kemampuan seorang karyawan dalam menjadi anggota koperasi.

2. Faktor dari luar

a. Faktor pinjaman dari luar

b. Para konsumen dari luar selain anggota koperasi

c. Pemerintah

TABEL 2

TANGGAPAN RESPONDEN

MENGENAI SISA HASIL USAHA

\begin{tabular}{|c|c|c|c|c|c|c|c|c|}
\hline \multirow[t]{3}{*}{$\mathrm{N}$} & \multirow[t]{3}{*}{ Pertanyaan } & \multicolumn{5}{|c|}{ Skor } & \multirow[t]{3}{*}{ Skor } & \multirow[t]{3}{*}{ Indeks } \\
\hline & & & & & & & & \\
\hline & & \multirow{2}{*}{$\begin{array}{r}\mathrm{SS} \\
5\end{array}$} & & \multirow{2}{*}{$\begin{array}{c}\mathrm{CS} \\
3\end{array}$} & \multirow{2}{*}{$\begin{array}{c}\mathrm{TS} \\
2\end{array}$} & \multirow{2}{*}{$\begin{array}{c}\text { STS } \\
1\end{array}$} & & \\
\hline & & & & & & & & \\
\hline 1 & Saya senang menjadi anggota koperasi SEHATI & 36 & 34 & 5 & 0 & 0 & 331 & 66,2 \\
\hline 2 & $\begin{array}{l}\text { Saya merasa puas dengan pelayanan yang } \\
\text { diberikan koperasi }\end{array}$ & 28 & 37 & 9 & 1 & 0 & 317 & 63,4 \\
\hline 3 & $\begin{array}{l}\text { kami anggota koperasi mendapat keuntungan dari } \\
\text { SHU berdasarkan jasa anggota }\end{array}$ & 21 & 43 & 8 & 3 & 0 & 307 & 61,4 \\
\hline 4 & $\begin{array}{l}\text { uang yang didapat dari hasil pembagian SHU } \\
\text { saya gunakan untuk hal positif }\end{array}$ & 32 & 37 & 5 & 1 & 0 & 325 & 65 \\
\hline 5 & $\begin{array}{l}\text { ketika saya membutuhkan uang koperasi sehati } \\
\text { bisa memberikan pinjaman }\end{array}$ & 37 & 29 & 9 & 0 & 0 & 328 & 65,6 \\
\hline 6 & $\begin{array}{l}\text { jumlah anggota koperasi setiap tahunnya selalu } \\
\text { meningkat }\end{array}$ & 25 & 36 & 14 & 0 & 0 & 311 & 62,2 \\
\hline 7 & $\begin{array}{l}\text { saya adalah anggota koperasi yang aktif dalam } \\
\text { setiap kegiatan }\end{array}$ & 26 & 32 & 15 & 2 & 0 & 307 & 61,4 \\
\hline 8 & koperasi selalu mempunyai modal cadangan di & 26 & 39 & 9 & 1 & 0 & 315 & 63 \\
\hline
\end{tabular}

http://ejournal.stiemj.ac.id/index.php/ekobis 


\begin{tabular}{|c|l|c|c|c|c|c|c|c|}
\hline & setiap tahunnya & & & & & & & \\
\hline 9 & $\begin{array}{l}\text { Setiap tahunnya koperasi memunculkan produk } \\
\text { atau gagasan/ide baru }\end{array}$ & 26 & 41 & 7 & 1 & 0 & 317 & 63,4 \\
\hline 10 & $\begin{array}{l}\text { setiap tahunnya pembagian SHU kepada anggota } \\
\text { selalu ada peningkatan }\end{array}$ & 29 & 37 & 8 & 1 & 0 & 319 & 63,8 \\
\hline \multicolumn{1}{|l|}{ Jumlah } & & & & & & 3177 & 635,4 \\
\hline & \multicolumn{1}{|l}{ Rata - Rata } & & & & & 318 & 63,54 \\
\hline
\end{tabular}

Sumber : hasil pengolahan data 2018

Keterangan :

Nilai jumlah $=331$ diperoleh dari $(5 \times 36)+(4 \times 34)+(3 \times 5)$

Nilai Indeks $=$ Nilai jumlah $/ 5=331 / 5=66,2$

Nilai Indeks Total $=(66,2+63,4+61,4+65+65,6+62,2+61,4+63+63,4+63,8) / 10=$ $635,4 / 10=63,54$

Berdasarkan, diketahui bahwa sebagian besar responden memberikan penilaian yang baik atas usaha koperasi dalam meningkatkan SHU yang rasakan oleh anggota koperasi Sehati. Rata rata skor jawaban variabel sisa hasil usaha diperoleh sebesar 63,54 yang berada dalam kategori skor "Tinggi" hal ini menunjukkan adanya kepuasan anggota sehingga peningkatan sisa hasil usaha yang diperoleh juga meningkat.

\section{Analisa Statistik dan Uji Hipotesis Pengujian Validitas}

Hasil uji coba instrumen penelitian untuk variabel Harapan Pelanggan, Kualitas Produk dan Kepuasaan Pelanggan berdasarkan hasil perhitungan validitas item instrumen yang dilakukan menunjukkan bahwa item-item pertanyaan dalam kuesioner valid karena skor $r_{\text {hitung }}$ lebih besar jika dibandingkan dengan $r_{\text {tabel }}$ yang bernilai $\mathbf{0 , 2 0 7 2}$ (nilai $r$ tabel untuk $n=90$ ).

\section{TABEL 3 \\ HASIL PENGUJIAN VALIDITAS VARIABEL X ( MANAJEMEN KOPERASI )}

\begin{tabular}{|c|l|c|c|c|}
\hline No & \multicolumn{1}{|c|}{ Pertanyaan } & & Ket \\
\hline 1 & $\begin{array}{l}\text { Perencanaan manajemen koperasi sehati dapat } \\
\text { meningkatkan kinerja koperasi }\end{array}$ & 0,641 & 0,2272 & Valid \\
\hline 2 & $\begin{array}{l}\text { Koperasi sehati memberikan pelayanan yang baik } \\
\text { kepada anggota }\end{array}$ & 0,632 & 0,2272 & valid \\
\hline 3 & $\begin{array}{l}\text { Koperasi menetapkan kebijakan SDM dalam } \\
\text { mencapai tujuan }\end{array}$ & 0,661 & 0,2272 & Valid \\
\hline 4 & $\begin{array}{l}\text { Koperasi menetapkan kebutuhan kerja } \\
\text { Karyawan }\end{array}$ & 0,560 & 0,2272 & Valid \\
\hline 5 & $\begin{array}{l}\text { Koperasi memberikan pengarahan pengawas kepada } \\
\text { anggota }\end{array}$ & 0,592 & 0,2272 & Valid \\
\hline 6 & $\begin{array}{l}\text { Koperasi memberikan pengarahan pengawas kepada } \\
\text { karyawan }\end{array}$ & 0,690 & 0,2272 & valid \\
\hline
\end{tabular}




\begin{tabular}{|c|l|c|c|c|}
\hline 7 & $\begin{array}{l}\text { Koperasi mengadakan pertemuan resmi antar anggota } \\
\text { koperasi }\end{array}$ & 0,559 & 0,2272 & Valid \\
\hline 8 & $\begin{array}{l}\text { Koperasi sehati mengadakan arus } \\
\text { informasi yang memadai }\end{array}$ & 0,618 & 0,2272 & Valid \\
\hline 9 & $\begin{array}{l}\text { Koperasi sehati memberikan pengawasan pengurus } \\
\text { terhadap karyawan }\end{array}$ & 0,646 & 0,2272 & Valid \\
\hline 10 & $\begin{array}{l}\text { Koperasi sehati memberikan pengawasan pengurus } \\
\text { terhadap anggota }\end{array}$ & 0,680 & 0,2272 & valid \\
\hline
\end{tabular}

Berdasarkan table 3 pada instrumen variabel X (manajemen koperasi) dapat diketahui bahwa nilai tertinggi terdapat pada dimensi manajemen koperasi dengan item pernyataan koperasi memberikan pengarahan pengawas pada karyawan yang bernilai 0,690 sedangkan nilai terendah terdapat pada pertanyaan koperasi mengadakan pertemuan resmi antar anggota yang bernilai 0,559 sehingga dapat ditafsirkan bahwa indeks korelasinya sangat tinggi. Untuk lebih rinci dapat dilihat pada tabel (variabel Y).

TABEL 4

\section{HASIL PENGUJIAN VALIDITAS VARIABEL Y ( SISA HASIL USAHA )}

\begin{tabular}{|c|c|c|c|c|}
\hline No & Pertanyaan & & & Ket \\
\hline 1 & Saya senang menjadi anggota koperasi SEHATI & 0,669 & 0,2272 & Valid \\
\hline 2 & $\begin{array}{l}\text { Saya merasa puas dengan pelayanan yang diberikan } \\
\text { koperasi }\end{array}$ & 0,660 & 0,2272 & Valid \\
\hline 3 & $\begin{array}{l}\text { Kami anggota koperasi mendapat keuntungan dari } \\
\text { SHU berdasarkan jasa } 0,501 \\
\text { anggota }\end{array}$ & & 0,2272 & Valid \\
\hline 4 & $\begin{array}{l}\text { Uang yang didapat dari hasil pembagian SHU saya } \\
\text { gunakan untuk hal positif }\end{array}$ & 0,463 & 0,2272 & Valid \\
\hline 5 & $\begin{array}{l}\text { Ketika saya membutuhkan uang, } \\
\text { koperasi sehati bisa memberikan pinjaman }\end{array}$ & 0,513 & 0,2272 & Valid \\
\hline 6 & $\begin{array}{l}\text { Jumlah anggota koperasi setiap tahunnya selalu } \\
\text { meningkat }\end{array}$ & 0,708 & 0,2272 & Valid \\
\hline 7 & $\begin{array}{l}\text { Saya adalah anggota koperasi yang aktif } \\
\text { dalam setiap kegiatan }\end{array}$ & 0,506 & 0,2272 & Valid \\
\hline 8 & $\begin{array}{l}\text { Koperasi selalu mempunyai modal cadangan disetiap } \\
\text { tahunnya }\end{array}$ & 0,724 & 0,2272 & Valid \\
\hline 9 & $\begin{array}{l}\text { Setiap tahunnya koperasi memunculkan produk atau } \\
\text { gagasan/ide baru }\end{array}$ & 0,612 & 0,2272 & Valid \\
\hline 10 & Setiap hatunnya pembagian SHU selalu meningkat & 0,679 & 0,2272 & Valid \\
\hline
\end{tabular}

Berdasarkan tabel 4 pada instrumen variabel sisa hasil usaha (SHU) dapat diketahui bahwa nilai tertinggi terdapat pada dimensi sisa hasil usaha dengan item pernyataan koperasi selalu mempunyai modal cadangan disetiap tahunnya yang bernilai 0,724 , sedangkan nilai terendah terdapat pada persepsi anda terhadap uang yang didapat dari pembagian SHU saya gunakan untuk hal positif yang bernilai 0,463 sehingga dapat ditafsirkan bahwa indeks korelasinya " sangat 
tinggi “.

Uji Reabilitas

TABEL 5

HASIL PENGUJIAN RELIABILITAS INSTRUMEN PENELITIAN

\begin{tabular}{|l|l|l|l|}
\hline No & Variabel & Alpha & Keterangan \\
\hline 1 & Manajemen Koperasi ( X ) & 0,827 & Reliabel \\
\hline 2 & Sisa Hasil Usaha ( Y ) & 0,803 & Reliabel \\
\hline
\end{tabular}

Dalam penelitian ini, Uji reliabilitas dilakukan dengan melihat hasil perhitungan nilai cronbach alpha ( a ). Suatu variabel dikatakan reliable jika memberikan nilai cronbach alpha (a) > 0,6 , yaitu bila dilakukan penelitian ulang dengan waktu dan dimensi yang berbeda akan menghasilkan kesimpulan yang sama. Tetapi sebaliknya bila alpha ( a ) < 0,6 maka dianggap kurang handal, artinya bila variabel-variabel tersebut dilakukan penelitian ulang dengan waktu yang berbeda akan menghasilkan kesimpulan yang berbeda (Imam Ghozali, 2006).

Hasil pengujian reliabilitas dalam tabel 4.9 menunjukkan bahwa semua variabel dalam penelitian mempunyai koefisien alpha ( a ) yang cukup bagus yaitu > 0,60 sehingga dapat dikatakan semua konsep pengukur masing-masing variabel dari koesioner adalah reliabel yang berarti bahwa kuesioner yang digunakan dalam penelitian ini merupakan kuesioner yang handal.

\section{Pengujian Regresi Linier Sederhana}

Regresi linear sederhana dilakukan untuk menentukan pengaruh sebuah variabel bebas (independen) terhadap variabel terikat (dependen).

TABEL 6

\section{HASIL UJI REGRESI LINIER SEDERHANA}

\begin{tabular}{|c|c|c|c|c|c|c|c|c|c|}
\hline \multirow[b]{3}{*}{ Model } & \multicolumn{8}{|c|}{ Model Summary } & \\
\hline & \multirow[b]{2}{*}{$\mathrm{R}$} & \multirow[b]{2}{*}{$\begin{array}{c}\mathrm{R} \\
\text { Square }\end{array}$} & \multirow[b]{2}{*}{$\begin{array}{c}\text { Adjusted } \\
\text { R } \\
\text { Square }\end{array}$} & \multirow{2}{*}{$\begin{array}{c}\text { Std. } \\
\text { Error of } \\
\text { the } \\
\text { Estimate }\end{array}$} & \multicolumn{5}{|c|}{ Change Statistics } \\
\hline & & & & & $\begin{array}{c}\text { R } \\
\text { Square } \\
\text { Change } \\
\end{array}$ & $\begin{array}{c}\mathrm{F} \\
\text { Change } \\
\end{array}$ & df1 & $\mathrm{df} 2$ & $\begin{array}{l}\text { Sig. F } \\
\text { Change }\end{array}$ \\
\hline 1 & $.706^{\mathrm{a}}$ & .498 & .491 & 3.00741 & .498 & 72.423 & 1 & 73 & .000 \\
\hline
\end{tabular}

a. Predictors: (Constant), Manajemen koperasi

b. Dependent Variable: Sisa hasil usaha

Berdasarkan tabel model Summary diatas, diketahui $\mathrm{R}$ yang merupakan symbol dari nilai koefisien korelasi adalah 0,706. Nilai tersebut dapat diinterpretasikan bahwa pengaruh kedua 


\section{JURNAL EKOBIS: EKONOMI, BISNIS \& MANAJEMEN Volume 9, Nomor 1, Maret (2019)}

variabel penelitian cukup kuat. Melalui tabel ini juga diperoleh nilai $\mathrm{R}$ square atau koefisien determinasi ( KD ) yang menunjukan seberapa bagus model regresi yang dibentuk oleh interaksi variabel bebas dan variabel terikat. Nilai KD yang diperoleh antara 49,8 \% yang dapat ditafsirkan bahwa variabel bebas ( $\mathrm{x}$ ) memiliki pengaruh kontribusi sebesar 49,8\% terhadap variabel $\mathrm{Y}$ dan $50,2 \%$ lainnya dipengaruhi oleh faktor-faktor lain di luar variabel $\mathrm{X}$.

TABEL 7. ANOVA

\begin{tabular}{|c|c|c|c|c|c|c|}
\hline \multicolumn{7}{|c|}{ ANOVA $^{b}$} \\
\hline \multicolumn{2}{|c|}{ Model } & $\begin{array}{l}\text { Sum of } \\
\text { Squares }\end{array}$ & df & $\begin{array}{l}\text { Mean } \\
\text { Square }\end{array}$ & F & Sig. \\
\hline \multirow[t]{3}{*}{1} & Regression & 655.030 & 1 & 655.030 & 72.423 & $.000^{\mathrm{a}}$ \\
\hline & Residual & 660.250 & 73 & 9.045 & & \\
\hline & Total & 1315.280 & 74 & & & \\
\hline
\end{tabular}

a. Predictors: (Constant), Manajemen koperasi

b. Dependent Variable: Sisa hasil usaha

Model regresi dikatakan layak jika angka signifikansi pada ANOVA sebesar $<0,05$, predictor yang digunakan sebagai variabel bebas harus layak. Kelayakan ini diketahui jika angka Standard error of estimate $<$ Standard deviation.

Pada data tersebut diketahui angka signifikasi pada ANOVA sebesar 0,000 $<0,05$ maka predictor yang digunakan layak.

TABEL 8. COEFFICIENTS

\section{Coefficients $^{\mathrm{a}}$}

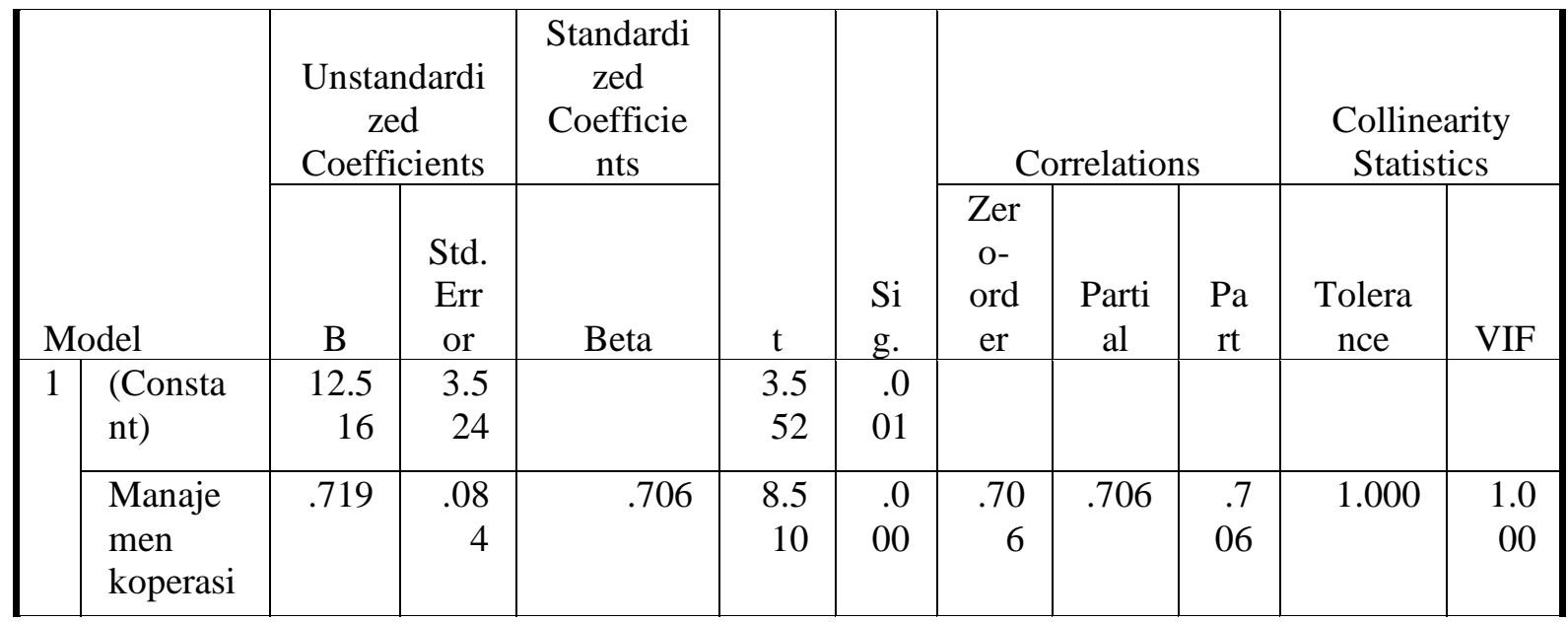

a. Dependent Variable: Sisa hasil usaha 


\section{JURNAL EKOBIS: EKONOMI, BISNIS \& MANAJEMEN Volume 9, Nomor 1, Maret (2019)}

Tabel tersebut menunjukan model persamaan regresi yang diperoleh dengan koefisien konstanta dan koefisien variabel yang ada dikolom unstandardized coefficients B, berdasarkan tabel diatas diperoleh model persamaan regresi : $\mathrm{Y}=12.516+0.719 \mathrm{x}$

\section{Pengujian Analisis Koefisien Korelasi Sederhana}

Analisis koefisien kolerasi di gunakan untuk mengetahui seberapa hubungan antara variabel $\mathrm{x}$ (manajemen koperasi) dengan variabel y (sisa hasil usaha). Dari hasil perhitungan akan diketahui besarnya nilai $\mathrm{r}$ ( koefisien kolerasi ) yang menunjukan kuat atau tidaknya hubungan kedua variabel.

\section{Tabel 9. Koefisien Korelasi Skor Hasil Perhitungan Kuesioner Manajemen Koperasi (X) Sisa Hasil Usaha (Y)}

\begin{tabular}{|c|c|c|c|c|c|c|c|c|c|c|}
\hline \multicolumn{11}{|c|}{ Model Summary $^{\mathrm{b}}$} \\
\hline $\begin{array}{l}\text { ModeR } \\
1\end{array}$ & & $\begin{array}{c}\text { R } \\
\text { Adjusted } \\
\text { Std. } \\
\text { Error of } \\
\text { Change } \\
\text { Statistics } \\
\text { Square } \\
\end{array}$ & $\begin{array}{c}\mathrm{R} \\
\text { Square }\end{array}$ & $\begin{array}{c}\text { the Estimate } \\
\text { R Square } \\
\text { Change } \\
\text { F Change } \\
\text { df1 } \\
\text { df2 } \\
\text { Sig. F Change } \\
\text { Watson }\end{array}$ & & & & & Dur & \\
\hline 1 & $.706^{\mathrm{a}}$ & .498 & .491 & 3.00741 & .498 & 72.423 & 1 & 73 & .000 & 1.429 \\
\hline
\end{tabular}

a. Predictors: (Constant), Manajemen koperasi

b. Dependent Variable: Sisa hasil usaha

Berdasarkan perhitungan tersebut dapat diketahui $r=0,706$ hal ini membuktikan hubungan antara manajemen koperasi dengan sisa hasil usaha koperasi SEHATI koefisien kolerasi 0,706 kategori kuat di antara 0,60 - 0,799. Jadi terdapat pengaruh yang kuat antara manajemen koperasi dengan sisa hasil usaha pada koperasi SEHATI.

\section{Pengujian Analisis Koefisien Determinasi}

Untuk mengetahui seberapa besar hubungan manajemen koperasi dan sisa hasil usaha (SHU) digunakan rumus koefisien determinasi sebagai berikut. 


\section{JURNAL EKOBIS: EKONOMI, BISNIS \& MANAJEMEN \\ Volume 9, Nomor 1, Maret (2019)}

\section{Tabel 10. Koefisien Determinasi}

\begin{tabular}{|c|c|c|c|c|c|c|c|c|c|c|}
\hline \multirow[b]{3}{*}{$\begin{array}{l}\text { Mode } \\
1\end{array}$} & \multicolumn{9}{|c|}{ Model Summaryb } & \multirow{3}{*}{$\begin{array}{c}\text { Durbin } \\
- \\
\text { Watso } \\
n \\
\text { Square } \\
\text { Chang } \\
\text { e }\end{array}$} \\
\hline & & & & $\begin{array}{c}\text { Std. } \\
\text { Error of }\end{array}$ & \multicolumn{5}{|c|}{ Change Statistics } & \\
\hline & $\mathrm{R}$ & $\begin{array}{l}\text { R } \\
\text { Squar } \\
\text { e }\end{array}$ & $\begin{array}{l}\text { Adjuste } \\
\text { d R } \\
\text { Square }\end{array}$ & $\begin{array}{c}\text { the } \\
\text { Estimat } \\
\mathrm{e}\end{array}$ & $\begin{array}{c}\text { R F } \\
\text { df1 } \\
\text { Chang } \\
\text { e }\end{array}$ & & & $\begin{array}{c}\text { df2 } \\
\text { Chang } \\
\text { e }\end{array}$ & $\begin{array}{c}\text { Sig. } \\
\text { F }\end{array}$ & \\
\hline 1 & $\begin{array}{r}.706 \\
\mathrm{a}\end{array}$ & .498 & .491 & 3.00741 & .498 & $\begin{array}{r}72.42 \\
3\end{array}$ & 1 & 73 & $\begin{array}{r}.00 \\
0\end{array}$ & 1.429 \\
\hline
\end{tabular}

a. Predictors: (Constant), Manajemen koperasi

b. Dependent Variable: Sisa hasil usaha

$$
\begin{aligned}
\mathrm{KD} & =\mathrm{r}^{2} \times 100 \% \\
& =(0,706)^{2} \times 100 \% \\
& =0,498 \times 100 \% \\
& =49,8 \%
\end{aligned}
$$

Dari hasil perhitungan tersebut di peroleh hasil koefisien determinasi sebesar $49,8 \%$, hal ini disimpulkan bahwa pengaruh manajemen koperasi terhadap sisa hasil usaha sebesar $49,8 \%$ sedangkan sisanya sebesar 50,2\% di pengaruhi variabel lainnya yang tidak di teliti.

\section{Pengujian Hipotesis ( uji t )}

Pengujian hipotesis di lakukan untuk mengetahui anipakah variabel independen (manajemen koperasi) berpengaruh terhadap variabel dependen (sisa hasil usaha). Pengujian hipotesis dilakukan dengan cara membandingkan nilai dengan .

\begin{tabular}{|c|c|c|c|c|c|c|c|c|c|c|}
\hline \multicolumn{11}{|c|}{ Coefficients $^{\mathrm{a}}$} \\
\hline & \multicolumn{2}{|c|}{$\begin{array}{l}\text { Unstandardiz } \\
\text { ed } \\
\text { Coefficients }\end{array}$} & $\begin{array}{c}\text { Standardiz } \\
\text { ed } \\
\text { Coefficien } \\
\text { ts } \\
\end{array}$ & & & \multicolumn{3}{|c|}{ Correlations } & \multicolumn{2}{|c|}{$\begin{array}{c}\text { Collinearity } \\
\text { Statistics }\end{array}$} \\
\hline Model & B & $\begin{array}{c}\text { Erro } \\
\mathrm{r}\end{array}$ & Beta & $\mathrm{t}$ & $\begin{array}{c}\text { Sig } \\
\text {. }\end{array}$ & $\begin{array}{c}\text { orde } \\
\mathrm{r}\end{array}$ & $\begin{array}{c}\text { Parti } \\
\text { al }\end{array}$ & $\begin{array}{c}\text { Par } \\
\mathrm{t}\end{array}$ & $\begin{array}{c}\text { Toleran } \\
\text { ce }\end{array}$ & VIF \\
\hline
\end{tabular}

Nilai signifikansi (a) sebesar $5 \%=0,05$

Derajat kebebasan $(\mathrm{df})=\mathrm{n}-2$, atau $\mathrm{df}=75-2=73$

TABEL 11. Hipotesis Uji t 


\section{JURNAL EKOBIS: EKONOMI, BISNIS \& MANAJEMEN}

Volume 9, Nomor 1, Maret (2019)

\begin{tabular}{|c|c|c|c|c|c|c|c|c|c|c|c|}
\hline 1 & (Constant & $\begin{array}{r}12.5 \\
16\end{array}$ & $\begin{array}{r}3.52 \\
4\end{array}$ & & $\begin{array}{r}3.55 \\
2\end{array}$ & $\begin{array}{r}.00 \\
1\end{array}$ & & & & & \\
\hline & $\begin{array}{l}\text { Manajem } \\
\text { en } \\
\text { koperasi }\end{array}$ & .719 & .084 & .706 & $\begin{array}{r}8.51 \\
0\end{array}$ & $\begin{array}{r}.00 \\
0\end{array}$ & .706 & .706 & $\begin{array}{r}.70 \\
6\end{array}$ & 1.000 & $\begin{array}{r}1.00 \\
0\end{array}$ \\
\hline
\end{tabular}

a. Dependent Variable: Sisa hasil usaha

Berdasarkan hasil SPSS diatas diketahui nilai 8,510 . Maka nilai $=0,025$

$$
\text { Df }=75-2=73 \text {, Nilai } .=1,993
$$

Karena nilai 8,510 lebih besar dari > . 1,993, sehingga dapat disimpulkan bahwa Ho ditolak dan Ha diterima, maka dapat dibuat hipotesis hubungan antara manajemen koperasi (x) terhadap sisa hasil usaha (y) pada koperasi SEHATI.

\section{Pembahasan Hasil Penelitian}

Pengukuran variabel penelitian dilakukan dengan menggunakan kuesioner yang dikembangkan dari indicator pada variabel penelitian. Dari hasil uji validitas terhadap variabel penelitian, ditemukan bahwa seluruh item pernyataan pada setiap variabel telah Valid. Melalui uji reliabilitas ditemukan bahwa seluruh butir pernyataan yang telah valid pada variabel penelitian dapat dibuktikan reliabilitasnya. Karena kuesioner telah valid dan reliabel maka kuesioner penelitian merupakan alat yang handal untuk mengukur variabel penelitian. Dimana persepsi responden terhadap pengaruh manajemen koperasi dalam meingkatkan sisa hasil usaha cenderung cukup baik.

Manajemen koperasi memiliki pengaruh positif yang signifikan terhadap peningkatan pendapatan SHU pada koperasi SEHATI, hal ini berdasarkan uji hipotesis parsial (uji t), dimana diperoleh sebesar 8,510 lebih besar dari $>$. 1,993. Selain itu dapat juga dilihat dari sign variabel manajemen koperasi sebesar $0,000<0,05$, maka Ho ditolak dan Ha diterima, artinya manajemen koperasi berpengaruh positif dan signifikan terhadap sisa hasil usaha pada koperasi SEHATI.

Penelitian ini sejalan dengan penelitian yang dilakukan oleh Ratih (2017) dan Purwati (2018) bahwa manajemen koperasi berpengaruh positif signifikan terhadap keberhasilan unit usaha toko koperasi, artinya bahwa adanya manajemen koperasi akan meningkatkan keberhasilan usaha toko koperasi.

\section{PENUTUP}

Dari penelitian yang telah dilakukan di Koperasi SEHATI mengenai "pengaruh manajemen koperasi dalam meningkatkan sisa hasil usaha (SHU)", dapat ditarik kesimpulan bahwa ada pengaruh positif dan signifikan antara manajemen koperasi dengan sisa hasil usaha, maka Ho ditolak dan Ha diterima, dengan membuktikan koefisien korelasi yang dihasilkan sebesar 0,706, hal ini menyatakan bahwa pengaruh antara variabel X dan Y adalah cukup kuat.

Penelitian ini menyimpulkan bahwa adanya pengaruh yang signifikan antara manajemen koperasi dengan sisa hasil usaha di Kopdit SEHATI. Hal ini sesuai dengan teori yang dikemukakan bahwa semakin baik manajemen koperasi maka akan mempengaruhi perolehan sisa hasil usaha koperasi. Manajemen koperasi sangat dibutuhkan untuk kemajuan koperasi 
kedepannya.

Manajemen koperasi hendaknya mengetahui pentingnya manajemen koperasi yang baik untuk kemajuan koperasi, suatu manajemen koperasi yang baik sangat dibutuhkan dalam koperasi, tanpa manajemen yang baik, koperasi tidak akan berjalan dengan baik.

Koperasi kredit yang dikelola sesuai dengan teori yang sudah ada pasti akan menghasilkan output yang lebih baik. Pembinaan koperasi diharapkan lebih memberikan pengetahuan serta wawasan terkait dengan pengelolaan koperasi kepada seluuh penurus dan anggota kopdit SEHATI.

\section{REFERENSI}

Alfiani, Winda 2016. Pengaruh Partisipasi Anggota Koperasi terhadap Sisa Hasil Usaha, Fakultas Ilmu Tarbiyah dan Keguruan, Universitas Islam Negri Syarif Hidayatullah Jakarta.

Arikunto, Suharsimi (2010). Manajemen Penelitian. Cetakan Kesebelas. Penerbit Rineka Cipta, Jakarta.

Buku AD/ART, Point dan Simpanan. Koperasi SEHATI Jakarta

Burhan, H.M, Bungin. (2013). Metodologi Penelitian Social dan Ekonomi. Jakarta: Kencana Prenada Media Group.

Cahyani, M. T., Zukhri, A., \& Meitriana, M. A. (2016). Pengaruh Jumlah Anggota terhadap Perolehan Sisa Hasil Usaha melalui Partisipasi Anggota sebagai Variabel Intervening pada Koperasi Simpan Pinjam Wisuda Guna Raharja Denpasar tahun 2012-2014. Jurnal Pendidikan Ekonomi Undiksha, 5(1).

Hendar dan Kusnadi (2005). Ekonomi Koperasi. Jakarta: Lembaga Penerbit Fakultas Ekonomi UI, Laporan Pertanggung Jawaban Pengurus Koperasi SEHATI Jakarta

Limbong, Bernhard, (2010). Pengusaha Koperasi. Jakarta: Margaretha Pustaka.

Pachta, Andjar, W, dkk, (2007).Hukum Koperasi Indonesia. Jakarta: Kencana Prenada Media Group.

Purwanti, Efi Suci (2018).Pengaruh Manajemen Koperasi dan Modal terhadap Keberhasilan Koperasi Serba Usaha Aktif di Kabupaten Tegal

Ratih, Agung dan Ayu Ida (2017). Analisis Faktor-Faktor yang Mempengaruhi Keberhasilan Koperasi Wanita di Kecamatan Gianyar

Reksohadiprodjo, Sukanto, 2010. Manajemen Koperasi. Yogyakarta: BPFE.

Sartika, Titik Partomo dan Soedjoedono, Abd Rachman.Ekonomi Skaka Kecil/ Menengah dan Koperasi. Bogor: Ghalia Indonesia, 2004

Sukamdiyo, Ign, 2006, Manajemen Koperasi, Penerbit Erlangga, Jakarta

Wati, L.N. 2018. Metodologi Penelitian Terapan Aplikasi SPSS,EVIWS,Smart PLS, dan AMOS. Edisi Kedua. Penerbit : CV. Pustaka Amri. Bekasi. 